\title{
What has Galilee to do with Jerusalem? Political aspects of the Jesus movement
}

\author{
Richard A Horsley \\ University of Massachusetts, Boston \\ Guest Lecturer, Department of New Testament, University of South Africa
}

\begin{abstract}
Adopting a perspective of class awareness, this study proposes that Jesus and his movements in Palestine did not simply have political implications but were engaged in social-political organising that brought them into political conflict with the Jerusalem and Roman rulers. This disposition has its roots in the distinctiveness of Galilee/Galileans as setting for Jesus and his followers.
\end{abstract}

\section{INTRODUCTION}

The rapidly shifting understanding of Jesus and the Jesus movement(s) in biblical and theological studies is integrally connected with several important realisations that have been gradually spreading in academic circles during the last two decades. Although individualistic readings still capture the imagination of many in Europe and the United States (Theissen 1978; Mack 1993), the individualism so peculiar to modern European and American culture is being challenged as anachronistic when applied to Jesus and his movement in ancient Palestine (Horsley 1989a). If the Jesus movement consisted simply of a bunch of individual itinerants with unconventional lifestyles, we cannot explain how communities ( $\dot{\varepsilon} \kappa \kappa \lambda \eta \sigma i \alpha \iota)$ emerge so quickly as the social form of the movements and as one of the principal concerns of the earliest 'Christian' literature. Secondly, although biblical studies is still institutionalised in theological schools and university departments of religion, there is a dawning awareness that 'religion' was not a dimension of life separable from the political-economic dimensions in traditionalsocieties, such as in ancient Palestine. The Jerusalem temple and the high priestly aristocracy based in it were political-economic as well as religious institutions. 'Kingdom of God' is a political symbol. It has even been suggested that language understood in Western bourgeois Christianity as primarily spiritual, likely had concrete meaning in the Jesus movements (Horsley 1987). 'Forgive us our debts as we herewith forgive our debtors' was probably heard with more than metaphoric implications. Is it possible, furthermore, that Jesus and his movements in Palestine did not simply have political implications, but were engaged in social-political organising that brought them into political conflict with the Jerusalem and Roman rulers? 
The determination of such issues depends heavily on what the concrete politicaleconomic-religious situation that Jesus and his movements faced was in Palestine. Here again our understanding has been shifting steadily and significantly during the last two decades ${ }^{1}$. Not only was 'Judaism' highly diverse, even in Palestine itself, but what we usually understand as Judaism had not yet emerged. It can only be referred to as 'nascent' or 'formative'. Its diversity was far more complicated than the four 'philosophies' mentioned by Josephus and labelled (probably inappropriately) 'sects' by modern European scholars. The Pharisees, Sadducees, Fourth Philosophy and Essenes/Qumranites all together must have comprised only a tiny fraction of the population of 'Jewish' Palestine (Saldarini 1988). The vast majority would have been resident in towns and villages at varying distances from Jerusalem, the centre of Herodian wealth, power, and privilege, as well as of the high priestly wealth, power, privilege based in the temple. According to the very structure of this religiously legitimated tributary political-economic system, the temple and priestly establishment was supported by the tithes, offerings, and other obligations of the ordinary people. Both the Christian gospel literature and the Jewish historian Josephus portray a persistent tension between the people of Palestine and their Jerusalem rulers (and their Roman imperial sponsors) which erupted periodically into overt conflicts (see Horsley \& Hanson 1985; Goodman 1987). Most dramatic were the massive popular insurrections in $4 \mathrm{BCE}$ and again in $66 \mathrm{CE}$, which neatly frame the ministry of Jesus roughly midway between them.

Besides the class divisions in Roman Palestine, now recognised by many scholars, there was also a regional difference between Galilee and Jerusalem/Judea which is only beginning to come into scholarly view (Horsley 1989a, 1995). Because this historical difference (compounded by class conflict) between Galilee and Jerusalem is directly pertinent to the Jesus movement, and because previous scholarly treatments of Galilee have obscured it, a direct focus on its implications may illuminate some of the salient political aspects of the early Jesus movements.

\section{GALILEE AND JERUSALEM: REgIONAL AS WELL AS CLASS DIF- FERENCES}

Galileans and Judeans/Jerusalemites presumably had common roots in Israelite traditions $^{2}$. For hundreds of years, however, their histories had taken divergent paths. After attaining independence as a people, ancient Israel had come under the rule of the Davidic monarchy in Jerusalem. Objecting to forced labour imposed to build the temple and other oppressive measures by Solomon, however, the ten northern Israelite tribes rejected Jerusalem rule and formed an independent kingdom. For the next eight hundred years the Israelites of Galilee, while usually subject to the same imperial regime - Babylonians, Persians, Ptolemies, Seleucids - were under separate provin- 
cial administration from the Judeans and Jerusalem. During those centuries Judea was reconstituted as a temple-state by the Persians, who also sponsored the writing of Judean traditions in 'the laws of Moses'. Given the ancient Near Eastern imperial practice of deporting mainly the ruling class of subject societies, while leaving the indigenous peasantry on the land, the population of Galilee probably remained primarily Israelite. Presumably the Galileans continued to cultivate their ancestral Israelite traditions, such as the Mosaic covenant, the Song of Deborah, and stories of (northern) prophets and holy men such as Elijah and Elisha (Draper 1994:35). The Galileans, however, were not subject to the temple-state or the official laws of Moses through which Judean society was governed by the high priestly aristocracy. Nor, so far as we know, did the Galileans go through the sharp repression of their traditional way of life by the Seleucid regime and the popular Maccabean revolt that brought the Hasmoneans to power in Jerusalem.

Indeed, it was not until the expansionist Hasmonean regime took over control of Galilee from the Iturean (104 BCE) during the decline of the Seleucid regime, that the Galileans again came under Jerusalem rule. This has been characterised in typical religious terms as a 'conversion' of the Galileans to 'Judaism,' whether a gradual voluntary conversion (Kasher 1988) or a militarily forced conversion (Grabbe 1992). If some sort of conversion was involved, it was not especially effective. The case of Costobar, Herod's military governor of Idumea, indicates that nearly a hundred years later even high-placed Idumeans were still cultivating the indigenous Idumean cult and customs. In any case, the concept of a personal individual or even collective change of religion seems inappropriate to what was clearly an incorporation of the people of a whole area under the rule of the Hasmonean temple-state. Josephus portrays the Hasmonean take-over of Galilee in much the same way that he does their earlier conquest of Idumea: the Hasmoneans allowed the inhabitants to remain in the land if they agreed 'to live according to the laws of the Judeans' ( $A J$ 13.319; cf 13.257). In Hellenistic historiography 'the laws of' a people is a standing idiom for the state's polity or 'constitution' (cf Cohen 1993; Horsley 1995). The decrees of Julius Caesar (cited by Josephus) confirming the Hasmonean power, refer similarly to 'the ancestral laws/ customs of the Judeans' according to which Hyrcanus and his successors were to rule and tax the people of Palestine ( $A J$ 14.190-210). The Hasmonean take-over of Galilee was not so much a religious conversion as an incorporation of the Galileans under the Jerusalem temple-state.

The implications of this incorporation are not far to seek - if we draw upon comparative historical sociology of agrarian societies (Lenski 1966). Galilean society, like Judean, would have consisted of scores of semi-autonomous village or town communi- 
ties. Local village affairs would have been conducted according to traditional Israelite customs, which presumably included Mosaic covenantal principles. The form of local self-governance and communal cohesion was the village assembly (כבשת Hebrew/Aramaic, $\sigma v \nu \alpha \gamma \omega \gamma \eta$ in Greek). The government maintaining social order and taxing the people was now the Hasmonean high priestly regime based in the Jerusalem temple. The political-economic relations between villagers and the central temple-based government, including whatever tithes and offerings were expected from the Galileans, would now have been structured according to 'the laws of the Judeans'. The principal questions are the degree to which the Hasmonean regime would have pressed obligations such as tithing and offerings upon their new subjects, and the degree to which the Jerusalem regime would have pressed for application of 'the laws of the Judeans' to local Galilean village affairs. A closely related question is: if there was some programme of pressing 'the laws of the Judeans' upon the Galileans, through what means that would have been pursued?

It seems unlikely, from what we know of Judean history at the end of the Hasmonean dynasty and the reign of Herod, that the Jerusalem government would have been interested in or in a position to press any programme on the Galileans ${ }^{3}$. Immediately following the annexation of Galilee, the king-high priest Alexander Janneus was engaged in further wars of expansion in the Golan and elsewhere as well as in a prolonged 'civil war' against his own people, apparently led by scribal elements who would ordinarily have worked for or with the regime (AJ 13.372-383, 400-403). Following the Roman conquest in $63 \mathrm{BCE}$, the combination of civil war between rival Hasmonean factions and the Roman civil war kept Palestine in periodic chaos. Judging from the Hellenistic style of his court and building programmes, including the rebuilt temple in Jerusalem, the Roman imposed strongman Herod would have had little concern to press 'the laws of the Judeans' on subject peoples in any way other than to ensure the steady flow of revenues to the Jerusalem temple and priesthood. The only period during which a programme of 'Judaisation' might have been pressed upon Galilee would appear to have been the short reign of Alexandra Salome (76-67 BCE). The only way such a programme would have been implemented would have been through the Pharisees, self-appointed guardians and interpreters of 'the laws of the Judeans'. The Pharisees held significant power under Alexandra Salome ( $A J 13.408-410)$. It is also conceivable that under Herod, when they suffered a diminution of power and position, the Pharisees may have found an appropriate outlet in cultivating the Judean laws among Galilean as well as Judean villages, perhaps precisely as a (somewhat defensive) way of preserving the traditional Judean way of life over against the encroachments of Roman Hellenism and Herodian tyranny. In any case, there appears to have been no 
energy or occasion for a major programme of forcing the Galileans to assimilate to 'the laws of the Judeans', although some Pharisaic advocacy of Judean concerns and customs in Galilee would appear likely at significant points during the first century BCE.

What followed the hundred years of direct rule of Galilee by Jerusalem appears as a puzzling complication in the relations between Galileans and the Jerusalem temple and priesthood. Ostensibly, with the Roman appointment of Herod's son Antipas as ruler in Galilee, Jerusalem no longer held direct jurisdiction over Galilee. In that new situation, however, we must reckon with the possibility of two forces competing for the resources of the Galilean peasantry. Antipas immediately launched an ambitious and costly building programme, first in rebuilding the city of Sepphoris and then in founding the totally new city of Tiberias, only 20 kilometres away, both apparently in the appropriate style for a client king who had been raised and educated in Rome ( $A J$ 18.27,36-38). The economic burden, and perhaps the cultural shock as well, on the Galilean peasantry, the only source of revenues, must have been intense and sudden. It would be difficult to imagine that the Jerusalem temple establishment suddenly relinquished its interest in revenues from Galilee in deference to the Galilean producers. In fact, once they no longer had direct jurisdiction over Galilee, including direct control over collection of revenues, the Jerusalem temple-based government would likely have sought ways of continuing their influence over and support from people previously attached/subject to the Temple-state. Again, the scribes and Pharisees would have been the obvious representatives of the Jerusalem high priestly government to press such interests in Galilee.

This sequence of events set up among the Galilean people precisely the situation that seems to be addressed by its earliest literary expressions of the Jesus movement(s). Three interrelated facets of this are discernible. Subjection to Jerusalem, with which the Galileans shared Israelite traditions, would have: (1) renewed and sharpened Galilean awareness of Israelite traditions. The Galileans had once again become united with other Israelites under the same state. Yet Galileans, like other units or groups within Israel, such as the Samaritans or the Qumranites who composed the Dead Sea Scrolls, (2) stood opposed to the Jerusalem rulers, perhaps even to rule from Jerusalem. The massive protest Josephus reports at Passover and Pentecost just after the death of Herod, which involved Galileans and others in addition to Judeans, provides a window onto the simmering resentment of high priestly as well as Herodian rule ( $A J$ 17.204-218,254-58). That the widespread popular insurrection which erupted shortly thereafter in Galilee as well as Judea and Perea took the distinctively Israelite social form of popular messianic movements ( $A J 17.271-85 ; B J 2: 56-55)$, rather than that a reform of the existing temple-state, suggests that the peasantry at least rejected the very system whereby they were ruled by a priestly aristocracy and/or client kingship 
from Jerusalem. The sharply punitive Roman reconquest followed by Antipas' burdensome (re-)building of the ruling cities of Sepphoris and Tiberias, with their alien political-culture, made more painfully evident Israel's renewed domination by alien imperial forces.

\section{THE POLITICS OF THE JESUS MOVEMENT(S)}

With their combination of a programme of renewal of Israel and prophetic condemnation of Jerusalem rule, along with Roman domination, the earliest literary expressions of the Jesus movement seem to have addressed just such a situation. Because so little attention had been given previously to the importance of class and regional differences in Palestine at the time of Jesus, it may be useful to consider a concept which has become standard among anthropologists and others in understanding conflicts between peasants and their lords, that of the dichotomy between 'the great tradition' and 'the little tradition'. An application of this concept to field studies of Southeast Asian villagers by James Scott also provides pertinent comparative material for consideration of the social-political programme and conflict evident in several key passages from the Synoptic Sayings Source and the Gospel of Mark.

Following Redfield, Scott (1977:8) defines 'the little tradition' as the distinctive patterns of belief and behaviour which are valued by the peasantry of an agrarian society, with 'the great tradition' being the corresponding patterns among the society's elite. The digressions between the two are rooted in and determined by the social differences between an elite enjoying political economic power and privilege, on the one hand, and subsistence-oriented producers living in relatively homogeneous villages where much of their life is governed by local custom (Scott 1977:4). At both levels, these 'traditions' function primarily in oral communication, although 'the great tradition' often exists also in written form such as a sacred scripture. The great tradition is often also the official law-code and policy-code of the society. These 'traditions' at both levels include political and economic affairs, which are often inseparable from the religious beliefs and practices of a people anyhow. This dichotomy of concepts should not be taken to imply that either the 'great' or the 'little' tradition is unitary. The contest for power among rival factions of the elite might involve significant variations among versions of the great tradition. Given the geographical and other differences among the peasantry of a society, the little or popular tradition would likely involve considerable variation. Nevertheless, 'subsistence-oriented cultivators all growing similar crops, all subject to a capricious nature, and all enmeshed in a wider state with its economic and political demands may well develop similar solutions to common problems' (Scott 1977:9). 
Insofar as these traditions at different social levels belong in the same society, they have a great deal in common, often offering different versions or twists on the same stories or customs or ceremonies. While there is ongoing interaction between them, they may be divided by considerable cultural distance. 'Just how much cultural distance separates them becomes an important analytical question' (Scott 1977:9). The degree of distance or closeness 'depends, in large part, upon how [the] great tradition developed' (Scott 1977:10). In some societies a specially educated group of guardians and interpreters of the official tradition constituted one mode of interaction and a potential mediating force between the two levels. As Scott points out, however, 'even when elite control is as pervasive as it was in the slave system, dominant classes are not completely successful in imposing their definition of reality on subordinate classes. What they achieve, at best, is ... an uneasy compromise between rejection and full endorsement of the dominant order .... The terms of subordination to a great tradition and its representatives are in this sense negotiated' (Scott 1977:15).

The 'little tradition' is the bearer of a whole popular culture that understands itself over against the official. 'The folk culture is not simply a crude version of its own great tradition. It functions also, both in form and content, as a symbolic criticism of elite values and beliefs' (Scott 1977:12).

The degree of popular subordination may thus depend upon particular historical dynamics. 'It would appear that the growth of oppression dialectically produces its own negation in the symbolic and religious life of the oppressed. At the very least this negation generates a new resistance to socialisation and moral instruction from above. At most, it represents the normative basis for rebellion and revolution' (1977:242). 'Under certain circumstances, forms of symbolic conflict may become manifest and amount to a political or religious mobilisation of the little tradition .... Whether the themes of subordination or of conflict prevail depends in large part ... on the material relations between peasantry and the elite' (Scott 1977:12). A major source of tension between the official and popular traditions is the very political-economic structure of agrarian societies. The elite, including the often literate exponents of the great tradition, live basically on what they extract from the peasantry in the forms of taxes, tribute, tithes, rents, and debts. 'When the economic surplus claimed by elites as a matter of right violates custom or imposes great hardships on the peasantry, it is likely to be resisted as unjust' (Scott 1977:16). Certain components of the popular tradition in fact, often 'establish moral ceilings on the economic claims which the great tradition may impose on subordinate classes' (Scott 1977:16). 
Many of the generalisations Scott makes about traditional agrarian societies in southeast Asia (under the impact of Western imperialism and an advancing capitalist economy) apply also to late second-temple Palestine (under the impact of Roman imperialism and client rulers). Because the ancient Palestinian peasantry left no written records - and we obviously cannot do 'field studies' of ancient Galilee in the way Scott did in Malaysia - we have virtually no direct evidence for the popular tradition among Galilean or Judean peasants. What became the Christian gospel literature, however, may provide windows here and there on just such popular tradition (as focal instances discussed below should illustrate). The divergent histories of Judea and Galilee indicate how, by the time of Jesus, the usual class divisions in an agrarian society, in which the respective 'great' and 'little' traditions were rooted, would have been compounded by regional differences.

Thus, when the Hasmoneans took over Galilee in 104 BCE, the Jerusalem templestate already had a long-standing official tradition embodied in 'the laws of the Judeans,' which presumably included the books of Moses, the 'Torah'. Since these laws had already been functioning as state law according to which political-economicreligious affairs were guided, the Jerusalem government simply applied them to the newly subjected peoples in Galilee and Idumea. The Galileans, however, who like the Judeans and their high priestly rulers were descendants of the ancient Israelites, already lived according to parallel or similar Israelite traditions. As we have discovered from the variations in text-types between the received Masoretic text and manuscripts discovered among the Dead Sea Scrolls and the variant Samaritan Pentateuch (Cross 1961: 188-194; Purvis 1968), even the Torah had not become completely standardised by late second temple times. There were periodic conflicts, moreover, between the rulers and their scribal 'retainers' such as the Pharisees about just how the official laws themselves were to be interpreted and applied, with the Pharisees promulgating additional 'traditions of the elders' not contained in the laws of Moses ( $A J$ 13.297). It is likely that there would have been even more variation among regional and local versions of popular tradition. The centuries of separate administration and historical experience between the Judean villagers and Galilean villagers would have resulted in variations of stories and customs. Even within Galilee, there would in all likelihood have been local variations among villages, just as there were among mediaeval English villages when the crown began collections of English common law.

We can imagine that there may still have been a predominance of similarities among at least the villages of Galilee, because of their common cultural ancestry, common life situation, and common subjection to rulers. The divergent histories of Judea and Galilee, however, would have left a greater variation between the popular tradition 
in the two areas; and a dramatic gulf between the official tradition of the Jerusalem priestly government and the Galilean villagers. The Jerusalem 'great tradition' had been formed to legitimate the temple-state in its position as ruling institution in Judea, under Persian imperial sponsorship. Moreover, it had been cultivated for centuries by officially designated scribal 'retainers' such as Ben Sira. The Pharisees were only the latest in a long sequence of such well-educated professional and politically powerful interpreters. In contrast to the Judean villagers who had already experienced centuries of interaction with the representatives of the official Jerusalem tradition, however, the Galilean villagers at the time of Jesus had been under Jerusalem rule little more than a hundred years.

Simply on the surface of the matter, there would appear to have been the potential of considerable divergence and conflict between the Galilean popular tradition and 'the laws of the Judeans' under which they had been living for only a few generations. Not only would the Galilean popular tradition not have been a 'crude version' of the official Jerusalem Torah, it would also have been developed long since in opposition to domestic as well as alien rulers. The foundational exodus story and Mosaic covenant, of course, celebrated liberation from oppressive rule and just social relations among an independent peasantry whose true ruler was God (to the exclusion of a human king). The Elijah-Elisha traditions, moreover, originally from the northern Israelite tribes in the first place, recounted divinely inspired and commissioned popular resistance against compromising and oppressive domestic rulers. And of course the stories of the northern Israelites' rebellion against Jerusalem rule after Solomon's death formed a specific memory in which renewed resentment of Jerusalem rule and taxation could have been rooted.

Thus the popular Israelite tradition in Galilee would easily have become the normative basis for resistance, even rebellion against Jerusalem along with foreign rule. Precisely the steadily increasing economic pressure of a triple layer of rulers with the corresponding triple layer of taxation that the Romans imposed in Herod, followed by the sudden impact of Antipas' massive building programmes in Lower Galilee, placed intolerable burdens on Galilean families and villages. The combination of tribute to Rome, continuing pressure for tithes and offerings to Jerusalem, and taxes to Antipas would have violated the 'moral ceiling' of acceptable exploitation rooted precisely in the Mosaic covenantal principles. Popular Israelite tradition in Galilee thus was the basis of appeal for a desperate people precisely in the generation of Jesus and his disciples.

The shift in assumptions currently underway in biblical studies makes a dramatic difference in the way the earliest documents of the Jesus movement read. Once we no longer automatically assume that the principal issue was a shift from one religion to 
another, and especially once we have a more concrete sense of the historical social context, the political-economic dimensions of the Synoptic Sayings Source ' $Q$ ' and the Gospel of Mark are unavoidable 4 . Sayings and stories previously read as legitimation of the shift in the 'divine economy' from 'Judaism' to 'Christianity' - and as key 'proof-texts' of Christian anti-Judaism - suddenly appear as manifestos of a movement challenging the established order headed by the temple-state and its imperial sponsor. The communities of Jesus followers, as a popular movement of renewal of Israel, also sharply opposed the ostensible head of Israel, the Temple and high priesthood in Jerusalem (Horsley 1987; Draper 1994). The basis of the challenge, judging from key passages in both $\mathrm{Q}$ and Mark, was Israelite popular tradition.

Most striking, perhaps, are Luke 22:28-30 and Matthew 19:28, particularly once we cut through the traditional Christian mistranslation that has been perpetuated even in the New Revised Standard Version. The $\dot{\varepsilon} \nu \tau \dot{\eta} \pi \alpha \lambda \iota \gamma \gamma \varepsilon \nu \varepsilon \sigma i \alpha$ of Matthew 19:28 should not be taken in the Stoic sense of regeneration of the cosmos (e g, Davies 1974; cf the NRSV paraphrase 'renewal of all things'). This term was standard for the historical restoration or reconstitution of the twelve tribes on the land (e g Josephus $A J 11.66$, 107). The most serious component in the misreading of this saying has been the

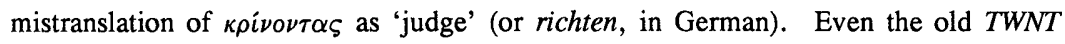
article had noted that in LXX and New Testament usage, $\kappa \rho i \nu \omega$, which was typically used to translate widow, or the orphan (e g, in the Psalms), carried the sense of deliverance, not distributive justice. This saying, which was probably the final, climactic saying in the Synoptic Sayings Source, thus proclaimed that the Twelve were to 'deliver' or 'liberate' the twelve tribes of Israel, not 'judging' Israel as the eschatological judge and jury of the newly constituted Christian dispensation that had replaced 'Judaism'.

As is becoming increasingly evident once we read the Gospel of Mark as a whole (and not carve it up into isolated 'pericopes'), the Jesus movement that produced Mark also understood Jesus' programme and themselves as the rene:val of Israel ${ }^{5}$. The sequences of stories about sea-crossings, healings, and feedings in the wilderness ( $\mathrm{Mk}$ 4:35-8:26) portray Jesus as the new Moses-and-Elijah, founder and restorer, respectively, of Israel. The appearance of the three together on the mountain (Mk 9:2-8) confirm that Jesus is engaged in the renewal of Israel. The appointment of the Twelve and their 'mission' in both Mark (3:13-19; 6:7-13) and Q (9:57-10:16) symbolises the reconstitution of Israel and the founding of Jesus' programme of renewal of and organising in local communities, village by village. Significantly, nothing in these passages suggests a mission to Gentiles. The imagery of the introduction to the 'mission discourse' in Q makes clear allusion to Elijah's commissioning of Elisha as the prototype of Jesus' commissioning of the disciples for the restoration of Israel. 
The renewal of Israel proclaimed by Jesus and underway in the movements that produced ' $Q$ ' and Mark did not exist in a political vacuum. That the renewal of Israel stood in direct opposition to the current rulers and ruling institutions is clear from closely related passages in Q. The people who 'come from east and west and from north and south' in Luke/Q 13:28-29 are not Gentiles streaming into the new religion, as traditional Christian exegesis would have it (Crossan 1983), but displaced Israelites now joining in the renewal of Israel, which is what 'the kingdom of God' refers to in Q! (and generally in synoptic Gospel literature; see Horsley 1987:190-199). Those who are cast out are (not 'the Jews' generally, but) those who typically put great stock in their genealogy as descendants of Abraham, Isaac, and Jacob, as legitimation for their positions of power and privilege, that is, the ruling families in Jerusalem. The very next saying in what must be the same discourse in Q, Luke 13:34, explicitly condemns the ruling house in Jerusalem, and in the form of a traditional Israelite prophetic lament, one type of oracle of condemnation. The divine agent, the 'I' of the oracle, is compassionate. Yet justice for the people is the primary principle, and the Jerusalem rulers are condemned for oppressing the villagers (the children/the hen's brood) and even killing the prophets God had sent to warn them. The orientation and perspective of both of these sayings is that of the popular Israelite tradition, which was full of prophetic protest and resistance against just such ruling class oppression.

Mark also portrays Jesus' renewal of Israel as developing in sharp conflict with the Jerusalem rulers and their representatives. That Jesus 'teaches' (acts) with authority ( $\dot{\xi} \xi o v \sigma i \alpha=$ power, for the benefit of the people, hence with resonance among them) is set over against the "authorities" lack of authority among (power on behalf of) the people at the beginning and climax of the narrative (Mk 1:21-28; 11:27-33). Jesus sharply criticises the scribes and Pharisees as representatives of the temple government (who 'come down from Jerusalem' 3:22; 7:1). Following his forceful (Jeremiah-like) prophetic demonstration in condemnation of the Temple, Jesus sharply indicts the rulers whose power was based there and their representatives, with clear allusions again to well-known prophetic traditions (e g, Mk 12:1-9; cf Isaiah 5:1-7), and finally prophesies the destruction of the Temple (13:2; cf 14:58; 15:29). Mark even has Jesus directly condemn Roman rule in the declaration that no tribute is really owed, since (as his audience would have understood) all things belong to God as their exclusive divine king. Since Jesus' conflict with the authorities escalates virtually from the beginning of the Gospel, it is unmistakable that his programme of renewal of the people is simultaneously a rejection of the ruling order based in Jerusalem. The story has hardly begun when Mark has the Pharisees and Herodians (representatives of the high priests and Antipas, respectively?) 'conspiring on how to destroy Jesus' (Mk 3:6), a purpose in 
which the rulers finally succeed once Jesus moves to a direct confrontation in Jerusalem itself (Mk 11:18; 12:12; 14:43-15:37). Despite Jesus' martyrdom for his cause, however, the movement continues its rejection of the Jerusalem ruling institutions (Mk 15:38), as well as its renewal of local communities in Galilee (Mk 14:28; 16:7).

Far from being provocative stimuli towards an itinerant lifestyle of individuals couched in isolated aphorisms, Q addresses the concerns of communities of people struggling to maintain subsistence and solidarity under difficult conditions of economic scarcity and political repression. The longest $\mathrm{Q}$ discourse (6:20-49), addressed specifically to community relations, not only contain particular covenantal exhortations, but constitutes a renewed Mosaic covenant in form as well as content. Continued focus on the individual sayings of this discourse and discussion of their 'sapiential' versus 'prophetic' character does not illuminate their function in Q (Koester 1990:137-38). Both the blessings and the admonitions have contents that are not typically sapiential (Kloppenborg 1987:188-189). The sayings in Q 6:27-36 in particular, however, do have a number of similarities to Israelite or Judean covenantal instruction (cf esp Lev 19:2, 918; Exod 23:4-5; Deut 22:1-4; Sir 29:1). Such sayings are rooted in popular cultivation of the traditional Mosaic covenant principles parallel to the official preservation of the same covenantal teachings in the 'Covenant Code' and the 'Levitical Code' which were taken up into the official scriptures of the Judean temple-state. The creativity of Jesus and/or his movement lies in the adaptation of traditional Mosaic covenantal forms as the structure of the discourse. It has long been recognised that Matthew's reworked version of the 'sermon' in Q (6:20-49) is structured in Mosaic covenantal form. This is particularly evident in the series of antithesis that quote explicitly from the decalogue, couching Jesus' exhortations as reformulations of the basic covenantal principles (Mt 5:20-48). A different version of most of the same sayings contained in Q 6:27-36 is linked with explicitly Mosaic covenantal principles rooted in the decalogue in Didache 1-2 as well. Since comparative study of the form of the Mosaic covenant in connection with Hittite suzereignty treaties (Mendenhall 1962; Balzer 1971), it has been recognised that structurally the Mosaic covenant framed the decalogue principles with a 'prologue' that proclaimed God's gracious acts of deliverance at the beginning and sanctions on observance of the principles such as blessings and curses at the end. It does not take much imagination to discern that the $Q$ 'sermon' has the same structure of prologue-principles-sanctions. Only now what had previously been the sanctions, the blessings and curses (which had long since been turned against the people in interpretation of their suffering as due to their own sinning), become declarations of God's imminent new deliverance (of the poor, versus the wealth! - Q 6:20-26, while the double parable of house-building becomes the sanction (6:46-49). At the centre of this 
proclamation of the renewed covenant are covenantal exhortations addressed specifically to the sorts of concrete social-economic problems faced by the people in their local communities, problems of local infighting and resentment resulting from the struggle for subsistence $(6: 27-36,37-38,41-42$; see further explication in Horsley 1987:265-273; 1991a:184-186).

Mark also has a covenantal discourse at a crucial juncture in the Gospel narrative. One section of the discourse even cites the decalogue in a pointedly explicit manner (Mk 10:17-22). Although Mark shapes this discourse out of what may seem (to the modern reader taking one 'pericope' at a time - that is, out of. literary context) quite separate stories, an overview of the whole discourse reveals a successive treatment of the same typical issues of community life as are dealt with in the Mosaic covenant: marriage and family (Mk 10:2-12, 13-16), economic resources (Mk 10:17-31), and social-political relations in the community/movement (Mk 10:41-45). Parallel to the $Q$ discourse, moreover, with its promised blessings of economic sufficiency and exhortation of mutual caring and cooperation, the Markan discourse also emphasises economic sufficiency and egalitarian mutuality in response to God's deliverance (esp Mk 10:17$31,41-44)^{6}$.

It is evident that the vision of Israel expressed in $Q$ discourses and Markan stories is very different from that focused in the Jerusalem temple-state. Besides being focused on local village social-economic relations in their renewal of Israel, the Jesus movements' condemn, in no uncertain terms, the ruling institutions in Jerusalem as unjust and repressive. The 'oral-literary' expressions of the Jesus movements do not look to reform or purify the Temple and high priesthood, but stand over against it. They are rooted not in an alternative 'reading' or 'interpretation' of a standardised scripture held in common with the Jerusalem authorities, but in a Galilean popular tradition that had developed independently of the official traditions based in Jerusalem. This is nowhere more evident than in the conflict between Jesus and the scribes and Pharisees in both $\mathbf{Q}$ and Mark.

The series of woes against the scribes and Pharisees in Q 11:39-52 has been interpreted as Jesus' advocacy of ethical law versus Pharisees' zeal for ritual law. A closer look at the rhetoric on the one hand, and the specific indictments on the other, indicates a more basic political-economic conflict. Although the rhetoric of the first woe throws their concern with purity codes back in their face, Q 11:39-41 indicts the scribes and Pharisees for extortion and evil. The rhetoric of the second woe, hyperbole about herbs that may not even have been subject to tithes, must be a caricature of the scribes' and Pharisees' role in advocating payment of tithes on the principal crops on which the priesthood as well as the peasants depended for basic sustenance. The 'justice and mercy and faithfulness/love' in Matthew 23:23/Luke 11:42 is not a quotation, but is 
clearly an allusion to several prophetic admonitions such as Micah 6:8, an indication of popular oral tradition. Again mocking their concern with purity codes, the indictment in Q 11:44 accuses the Pharisees themselves of being a danger to the people. Nothing in Q 11:46 suggests that the burdens that the lawyers/scribes and Pharisees place on the people involve legalism or rituals. The burdens here, like the poverty and hunger in the beatitudes (Q 6:20-21) and the food and debts in the Lord's Prayer (Q 11:2-4) are more likely concretely economic: tithes and taxes. The reference to 'touching the burdens with one of your fingers' points out that it was within their power, as interpreters of 'the laws of the Judeans', to alleviate the people's burdens. That the scribal representatives of the temple-state tend the tombs/graves of the prophets (11:47-48) is the final irony for Q's Jesus, who stands precisely in the line of those prophets in pronouncing indictments against official injustice. The concluding indictment in $Q$ 11:52 is a summary of the overall effect of the scribes' and Pharisees' actions on the people: they prevent them from entering the kingdom of God. The series of woes is a sustained indictment of the scribal 'retainers' of the temple-state for the effect of their official functions on the people. That function is to press the tithing and other official laws on the people. From the perspective of Q's Jesus, rooted in the Israelite prophetic traditions of 'justice and mercy,' their function is tantamount to extortion.

While only implicit behind the woes in Q 11:37-52, the Israelite popular or 'little' tradition is explicitly set over against the official or 'great' tradition of the scribes and Pharisees in Mark 7:1-13 (23). The conflict in this 'pronouncement story' is not over 'the Law' or between 'the written law' versus 'the oral law.' It is rather between 'the traditions of the elders' and 'the commandment of God.' Both are apparently in oral tradition. Josephus' discussion of the historical role of the Pharisees in propagating certain paradosis not written in 'the laws of Moses' ( $A J$ 13.297) illuminates the conflict in Mark 7. The scribes and Pharisees, as part of their function in the temple-state, promulgated supplementary regulations supplementary to the Torah proper, in this case

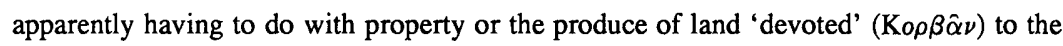
Temple. The story may start out with an accusation of violating the purity codes by the scribes and Pharisees. Jesus, however, quickly changes the focus to the deleterious economic effects which the representatives of Jerusalem's interests have on the people: draining off economic resources needed at home simply to support the elderly family members who are no longer productive. Thus the effect of the scribal functions are a violation of the basic covenantal commandment of God to 'honour father and mother'. The Mosaic covenant remained the basic guide to social-economic life in the villages of Galilee. The heavy drain of economic resources by their multiple layers of rulers was a violation of their fundamental rights rooted in Israelite covenantal tradition. 
Several simultaneous shifts in our understanding are conspiring to open to view a very different picture of the movements of Jesus' earliest followers. As the standard old theological paradigm of Christian origins from 'Judaism' disintegrates before ever more precise knowledge of the complexity of the historical situation in Palestine in late second temple times, and European and North American scholars see past their own individualism and division of historical reality into separate compartments of religion and pclitics, the orientation of the Synoptic Sayings Source and the Gospel of Mark to the concrete political-economic-religious situation of contemporary Roman Palestine comes into view. Both of these early documents represent Jesus and his movement(s) as engaged in the renewal of Israel over against the rulers and ruling institutions in Jerusalem. It may not be due solely to modern presuppositions and approaches that scholars have not previously discerned this very clearly. Not long after the emergence of $\mathrm{Q}$ and Mark as expressions of the first generation of Jesus followers, the widespread popular insurrection in Galilee as weil as Judea was devastatingly suppressed by Roman armies. The Jesus movements that produced $Q$ and Mark may not have survived after 70. And shortly thereafter, or so subscribers to the current consensus on 'the Synoptic Problem' believe, Matthew and Luke subsumed both Mark and Q into Christian Gospels that made significant adjustments to the new political realities of a more stringent imperial situation. With those adjustments Christianity was on its way to becoming a 'religion' with less disruptive social implications.

\section{End Notes}

1 Studies of Jesus, the Jesus movements, and the Gospel tradition are having difficulties in shedding the continuing influences of the old theologically-determined scholarly paradigm of the emergence of one religion, Christianity, from another, Judaism. Ironically, the very attempt to take seriously the historical context of Jesus in Palestine has led to the realisation that the standard conceptual apparatus for that context may be blocking fuller historical understanding.

2 A more detailed and documented presentation of the historical sketch in this section appears in Horsley 1995,chapter 1 and 2.

3 More extensive presentation and documentation of the following section appears in Horsley 1995, chapter 1 and 2.

4 The political engagement of the Gospel of Mark has been explored particulatly by Myers (1988). Recent attempts to secure definitively different strata in Q, from which a precise history of a Jesus movement can then be constructed (Mack 1988, building on Kloppenborg 1987), are based on a highly questionable modern scholarly dichotomy between 'apocalyptic' and 'sapiential' sayings and worldviews. Criticism of such 'stratigraphy' of $Q$, including the recognition that little 'apocalyptic' materials can be found in Q, is spreading (Yarbo Collins 1989; Collins 1993; 
Horsley 1989, 1991 a \& b). As implied in Kloppenborg (1987), Q is not a collection of sayings similar to the Gospel of Thomas, but a sequence of discourses more analogous to the Didache (Horsley 1991b; Draper 1994).

5 On the lasting impact of recent developments in literary-critical analysis, such as 'narrative' and 'reader-response' criticism, see the reflections in Horsley 1994:11, 46-50. I fully agree with Botha (1991:305) that analytical concepts such as 'narrative' and 'literature' cannot be divorced from historical communication contexts (as many literary analysts assume in practice). If 'Mark' was 'oral literature', composed and recited with slight variations at various performances (Botha 1991: 307), then the overall agenda of renewal of Israel and the dramatic political conflict evident in the 'plot' of the story as a whole become all the more significant.

${ }^{6}$ I owe the recognition that $\mathrm{Mk}$ 10:17-31 addresses a village situation to students from Burma and the Philippines, that is, from more traditional agrarian societies, who were members of a seminar at Harvard Divinity School, fall term, 1990.

\section{WORKS CONSULTED}

Balzer, K 1971. The covenant formulary in Old Testament, Jewish, and Early Christian writings. Philadelphia: Fortress.

Botha, P J J 1991. Mark's story as oral traditional literature: Rethinking the transmission of some traditions about Jesus. HTS 47, 304-331.

Collins, J J 1993. Wisdom, apocalypticism, and generic compatability, in Perdue, L G et al (eds), In search of wisdom: Essays in memory of John H Gammie, 165-186. Louisville: Westminster/John Knox.

Cross, F M 1961. The ancient library of Qumran and modern Biblical studies. Garden City, NY: Doubleday.

Crossan, J D 1983. In fragments: The aphorisms of Jesus. San Francisco: Harper \& Row.

Davies, W D 1974. The gospel and the land: Early Christianity and Jewish territorian doctrine. Berkeley: University of Califormia Press.

Draper, J A 1994. Jesus and the renewal of local community in Galilee. Journal of. Theology for Southern Africa 87, 29-42.

Goodman, M 1987. The ruling class of Judaea: The origins of the Jewish revolt against Rome A.D. 66-70. Cambridge: Cambridge University Press.

Graibe, L 1992. Judaism from Cyrus to Hadrian. 2 vol. Minneapolis: Fortress.

Horsley, R A 1987. Jesus and the spiral of violence: Popular Jewish resistance in Roman Palestine. San Francisco: Harper \& Row. 1989a. Sociology and the Jesus movement. New York: Crossroad. 
Horsley, R A 1989b. Questions about redactional strata and the social relations reflected in Q, in Lull, D J (ed), Society of Biblical Literature 1989 Seminar Papers, 186-203. Atlanta: Scholars Press.

- 1991a. Q and Jesus: Assumptions, approaches and analyses. Semeia 55, 175209.

1991b. Logoi Propheton? Reflections on the genre of Q, in Pearson, B et al (eds), The future of Early Christianity: Essays in honor of Helmut Koester, 195209. Minneapolis: Fortress.

— 1995. Galilee: History, politics, people. Philadelphia: Trinity Press International.

Horsley, R A \& Hanson, J S 1985. Bandits, prophets and messiahs: Popular movements in the time of Jesus. Minneapolis: Winston.

Kasher, A 1988. Jews, Idumeans, and ancient Arabs. Tübingen: Mohr.

Kloppenborg, J S 1987. The formation of Q: Trajectories in ancient wisdom collections. Philadelphia: Fortress.

Koester, H 1990. Ancient Christian Gospels: Their history and development. Philadelphia: Trinity Press International.

Lenski, G E 1966. Power and privilege. New York: McGraw Hill.

Mack, B L 1988. The kingdom that didn't come: A social history of the Q tradents, in Lull, D J (ed), Society of Biblical Literature 1988 Seminar Papers, 608-635. Atlanta: Scholars Press.

1993. The lost Gospel. San Francisco: Harper Collins.

Mendenhall, G E 1962. s v Covenant. IDB 1, 714-723.

Miller, R J 1988. The rejection of the prophets in Q. JBL 89, 405-417.

Myers, C 1988. Binding the strong man: A political reading of Mark's story of Jesus. Maryknoll: Orbis.

Purvis, J D 1968. The Samaritan Pentateuch and the origin of the Samaritan sect. Cambridge: Harvard University Press.

Saldarini, A J 1988. Pharisees, scribes, and Sadducees in Palestinian society: A sociological approach. Wilmington: Glazier.

Scott, J C 1977. Protest and profanation: Agrarian revolt and the Little Tradition. Theory and Society 4, 1-38, 210-246.

Theissen, G 1978. Sociology of early Palestinian Christianity. Philadelphia: Fortress. Yarbro Collins, A 1989. The son of man sayings in the sayings source, in Horgan, $\mathbf{M}$ $\mathrm{P}$ and Kobelski, P J (eds), To touch the text: Biblical and related studies in honor of Joseph A Fitzmyer, S J, 369-389. New York: Crossroad. 